\section{A TYPOLOGICAL APPROACH TO THE PASSIVE IN THAI ${ }^{1}$}

\section{Amara Prasithrathsint ${ }^{2}$}

\begin{abstract}
Based on the generalization and classification of passives in the world's languages put forward by Givón (1979), Siewierska (1984), and Keenan (1990) this study recapitulates the universal types of passive. Twenty types of passive are proposed. They are grouped into ten pairs of contrastive types; namely, passive vs. ergative, true passive vs. pseudo-passive, direct vs. indirect passive, sentential vs. lexical passive, personal vs. impersonal passive, plain vs. reflexive passive, neu cal vs. adversative or favorable pas: ve, basic vs. non-basic passive, synthetic vs. periphrastic passive, passive with patient subject vs. passive with non-patient subject. It is found that five of these pairs are applicable to the
\end{abstract}

${ }^{1}$ The content of this paper is based on a part of the research report on "Controversial constructions in Thai Grammar: Relative clause constructions, complement clause constructions, serial verb constructions, and passive constructions". The study was funded by the National Research Council of Thailand and conducted by Pranee Kullavanijaya, Kingkarn Thepkarnjana, and myself in 2003. I was responsible for the part on passive constructions. In the process of revising and improving this paper, I was very grateful to Pranee Kullavanijaya for her constructive comments and suggestions.

${ }^{2}$ Associate Professor, Department of Linguistics, Faculty of Arts, Chulalongkorn University analysis of passive types in Thai. A typological system of passives in Thai is proposed. It comprises eight actual types of passive, which are distinguished from one another by these features: [true], [neutral], [direct], [basic], and [synthetic].

\section{Introduction}

The purpose of this study is to approach passives typologically and to classify the passive in Thai into types.

One of the reasons why I have attempted to analyze passives typologically is that there has been a great deal of confusion as to how to analyze passives, chiefly because different models of grammar treat passives differently; for example, as to whether passives are structurally related to actives; i.e., whether they are derived transformationally from their active counterpart or are derived independently. Among those who maintain that passives are related to actives by syntactic rules are Chomsky (1965, 1973), Fillmore (1968, 1971), and Emonds (1976). Those who contend that actives and passives are syntactically independent but related by lexical rules are, for example, Shopen (1972), Bresnan (1978), and Starosta (1988). Yet, there are some who hold that some passive clauses are derived transformationally and other passive clauses lexically, for example, Wasow 1977, Lightfoot 1979, and Bennett 1980 (cited in Siewierska 1984:7).

Another reason why a typological approach to passives is adopted here is that it is very likely to yield solutions to the problem of identifying and classifying passives, which can serve as a basis for further analysis. In many earlier analyses, passives were defined 
differently according to different criteria. This resulted in the conclusion that some languages have passives but others do not. Thai is a good example of such a language. Indeed, several linguists maintain that Thai does not have passives. However, many others, myself included argue that it does. My view is that passives are diverse and do not have a uniform pattern.

\section{Universality of passives}

Functionally speaking, passives serve the same function in the world's languages. According to Keenan (1990: 243-244), passives may be considered foregrounding constructions, which topicalize or foreground an element. In John was slapped, John is presented as topical, unlike in Mary slapped John. Other foregrounding devices are topicalizations or left-dislocation (e.g. Beans I like). Passives are different from topicalized constructions in that they can eliminate the subject of the active or relegate it to the status of an oblique NP (as in John was slapped by Mary).

Based on evidence from a large number of languages around the world, Keenan (1990: 241) argues that "no language forms passive sentences by assigning a characteristic to an active, or by inserting a sentence-level particle in an active, or by inverting the subject and the auxiliary of an active. Rather, passives are formed by deriving verb phrases in certain ways."

Keenan divides all passives into two major types: basic and non-basic or complex passives. The term "basic passives", refers to passives that have three characteristics: 1) They have no agent; 2) the passivized verb is a transitive verb; and 3) the passivized verb is an activity verb, e.g., John was slapped. Passives that do not have these characteristics are complex, or nonbasic, passives. Based on several criteria, such as the presence of an agent, types of verbs that can be passivized, aspectual differences, and degree of subject affectedness, Keenan made generalizations about the distribution of all the world's passives, which are summarized as follows:

G-1 Some languages have no passives.

G-2 If a language has passives, it has ones characterized as basic; moreover, it may have only basic passives.

G-2.1 If a language has passives with agent phrases, then it has them without agent phrases.

G-2.2 If a language has passives of stative verbs (e.g. lack, have, etc.), then it has passives of activity verbs.

G-2.3 If a language has passives of intransitive verbs then it has passives of transitive verbs (e.g. in Japanese).

G-3 Languages with basic passives commonly have more than one formally distinct passive construction.

G-4 If a language has passives, it has ones which can be used to cover the perfective range of meaning.

G-5 If a language has two or more basic passives, they are likely to differ semantically with respect to the aspect ranges they cover. 
G-6 The subject of a passive VP is never understood to be less affected by the action than when it is presented as the object of an active transitive verb.

G-7 Distinct passives in a language may vary according to the degree of affectedness of the subject and whether it is positively or negatively affected (e.g. in Thai, Vietnamese, Chinese), though this variation seems less widely distributed than that of aspect.

G-8 If a language can passivize transitive verb phrases taking sentential objects then it can passivize ones taking lexical noun phrase objects.

G-9 If a language presents basic passives, then it always passivizes 'give', 'show', etc. in such a way that the derived subject is the Patient of the active verb. Passives in which the Recipient is the subject may or may not exist (e.g. in French such a sentence as Le livre a eté donné à Pierre. 'The book was given to Pierre' is grammatical, but *Pierre a été donné le livre. 'Pierre was given the book' is ungrammatical.)

(Keenan 1990: 247-277)

It is interesting to note that studies of passives in Thai and other Tai languages provide evidence that seems to confirm many of Keenan's generalizations. For instance, G-1, which states that some languages have no passives, is confirmed by the fact that some Tai languages, such as Ahom Tai, and Phutai do not have passives. This is also true of the Thai used in the Sukhothai,
Ayutthaya, and early Bangkok periods. (Prasithrathsint 2004).

The fact that Thai has both basic and non-basic passives and that it has more than one formally distinct passive construction supports the statements in G-2 and G-3.

Concerning G-4 and G-5, that passives in Thai seem to be compatible with perfective aspect may be regarded as supporting the generalizations. However, such a claim needs further investigation. (See the discussion following (24) and (25) in 4.7.)

G-6 may need proof from a test of native speakers' reaction. However, based on my observation, native speakers of Thai seem to passivize a transitive active sentence or depassivize a passive sentence quite freely. This seems to imply that the object of an active sentence and the subject of its passive counterpart are equivalent in terms of the degree of its being affected by the action of the verb.

The findings about passives in Thai also provide evidence supporting G-7 and G9. Indeed, Thai has adversative, favorable, and neutral passives. Unlike in French, in Thai both the passive with the Patient subject and that with the Recipient subject exist. The latter is classified as the indirect passive. (See 4.3)

With reference to G-8, the passive with a sentential subject is less common than the passive with a noun phrase subject. The fact that Thai has only the latter type of passive supports the statement in G-8. 


\section{Definition of passive and passivization}

Givón (1979: 187) defines passivization from a functional point of view as "the process by which a non-agent is promoted into the role of main topic of the sentence. And to the extent that the language possesses coding properties which identify main topics as subjects and distinguishes them from topics, then this promotion may also involve subjectivalization."

Based on a comparative analysis of passives in many different languages, Siewierska (1984) defines passive constructions as those which have the following characteristics:

a) the subject of the passive clause is a direct object in the corresponding active;

b) the subject of the active clause is expressed in the passive in the form of an agentive adjunct or is left unexpressed;

c) the verb is marked passive.

(Siewierska 1984: 2-3)

In this paper, "passive" is also defined by a combination of characteristics. A passive construction is a construction that has all of the following characteristics:

(1) Its grammatical subject corresponds to the object in its active counterpart.

(2) Its main verb is an intransitive verb derived from a transitive verb in the active counterpart.

(3) It is marked by adding an affix to the main verb or a word to the passive sentence.

(4) It may or may not contain an agent.

(5) It may differ in form and meaning from other types of passive in the same language.

As will be seen, the above definition covers all the types of passives described in the following sections.

\section{Types of passives in the world's languages}

Based on Givón (1979), Siewierska (1984), and Keenan (1990), I classify passives universally into 20 types, which are grouped into 10 pairs. The features that distinguish the two types in each pair are a dichotomy of contrastive features. It should be noted that these features are not mutually exclusive. For instance, basic passives can also be synthetic, neutral, personal, plain, etc. Here, I arrange all the pairs of features on the basis of their role in classifying languages into types concerning passives. The features that affect more languages are more general than those that affect fewer languages. The ten dichotomies of features are ordered from the most general to the most specific as follows.

1. Passive vs. ergative (passive-like constructions)

2. True passive vs. pseudo-passive

3. Direct passive vs. indirect passive

4. Sentential passive vs. lexical passive

5. Personal vs. impersonal passives

6. Plain passive vs. reflexive passive

7. Neutral passive vs. adversative or favorable passives

8. Basic vs. non-basic passives 
9. Synthetic vs. periphrastic passives

10. Passives with patient subjects vs. passives with non-patient subjects

\subsection{Passive vs. ergative (passive- like constructions)}

Evidence from typological research shows that passives are normally found in accusative languages as opposed to ergative languages. In accusative languages, active sentences, in which the subject is Agent, are unmarked, and passive sentences, in which the subject is Patient, are marked. On the other hand, in ergative languages, constructions with Patient subjects are unmarked. They are known as "ergative" constructions. Their counterpart is the "anti-passive" construction, in which the subject is Agent, and it is marked.

Based solely on the semantic criterion, any linguist might consider an ergative construction to be passive. However, most linguists seem to take into consideration grammatical markers and consider ergative to be unlike passive. Examples (1) and (2) are Dyirbal ergative and anti-passive, respectively.

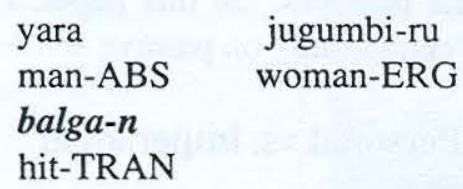

(Dyirbal)

'The man was hit by the woman.'

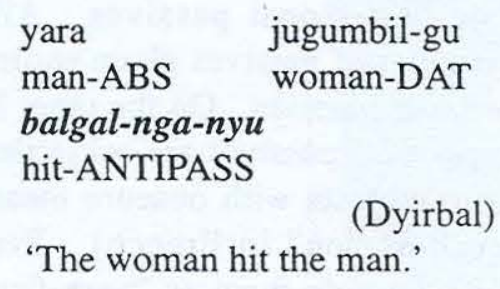

'The woman hit the man.'

It should be remarked that (1) is passivelike semantically. However, the verb /balga-n/ 'hit' is an unmarked transitive and there is no other marker in the sentence like a passive sentence in accusative languages. In contrast, the verb /balgal-nga-nyu/ in (2) is fully marked, so that the sentence becomes opposite to (1) in terms of semantic roles. It is active-like semantically but labeled as "anti-passive" in ergative languages.

\subsection{True passive vs. pseudo- passive}

An important marker of a "true passive" is that the main verb is derived from a transitive verb. If it is derived from an intransitive verb, the construction will be labeled as a "pseudo-passive". In other words, a pseudo-passive is a passive-like construction in which the verb is derived from an intransitive verb, as the verbs/pay/ 'go', and/jok/ 'leave' in (3) and (4).
(3) khăw thuiuk pay he PASS go prachum thęn hǔa-nâa meeting instead boss lǎay khrán several time

'He has been made to attend meetings on behalf of his boss several times.'

khăw doon jok càak
he PASS leave from
râatchakaan phró tham
public service because do
khwaam-phìt
wrong
'He was made to resign from being a civil servant because he had done wrong.' 


\subsection{Direct passive vs. indirect passive}

Direct passives are passives in which there is a direct relationship between the verb and the subject of the passive sentence in terms of affectedness. In contrast, indirect passives are passives in which there is no relationship between the subject of the passive sentence and the verb, such as (5) and (6).

$$
\begin{aligned}
& \text { taroo ga doroboo ni } \\
& \text { Taroo NOM thief AGT } \\
& \text { zitensha o nusum-are-ta } \\
& \text { bike ACC steal-PASS-PAST } \\
& \text { (Japanese) } \\
& \text { 'Taroo was affected by his } \\
& \text { bike being stolen by a thief.' }
\end{aligned}
$$

(Siewierska 1984:155)

$$
\begin{aligned}
& \text { chăn thuúk phłan yíp năys̆̀̀ } \\
& \text { I PASS friend pick book } \\
& \text { pay dooy mây bj̀ok } \\
& \text { go by not tell }
\end{aligned}
$$

"I was affected by my friend's taking that book without telling me.'

As can be seen in Examples (5) and (6), the Patient of the verb 'steal' and 'pick' is 'bike' and 'book', respectively. However, they are not subjects. This makes the sentences different from direct passives. However, since the sentences are marked by a passive marker: /rare/ in Japanese, and /thúuk/ in Thai, they can be regarded as passives, but are labeled as "indirect passives" here.

\subsection{Sentential passive vs. lexical passive}

Some linguists divide passives into two types based on whether they are sentences or lexical items. All the examples shown earlier are passive sentences.

Lexical passives, on the other hand, are not sentence constructions, but words, such as broken in a broken glass, damaged in a damaged car, interested in The audience interested in this topic can attend my lecture on Monday, etc. These words with "passive meanings" may be called "participial passive" (Beedham 2001) or "adjectival passive participle” (Yumoto 1991).

Another kind of lexical passive was proposed by Irube (1984); namely, adjectives ending with "-able" which have "passive" meanings; for example, debatable ('that can be debated'), forgivable ('that can be forgiven'), separable ('that can be separated'), countable ('that can be counted'), perceivable ('that can be perceived').

It may be important to note that most linguists who deal with passives in various languages in the world focus on passive sentences and tend to ignore lexical passives. In this paper, I also concentrate only on passive sentences.

\subsection{Personal vs. impersonal passives}

Personal passives have subjects with clear meanings. They are more common than impersonal passives. All the examples of passives given earlier are personal passives. On the other hand, impersonal passives are subjectless or have subjects with obscure meanings (such as "on" in French). Berman (1979) labels them as "verb-first" or 
"missing-person constructions", as (7)(10) below.

$$
\begin{array}{lc}
\text { otobüse-e } & \text { bin-il-di } \\
\text { bus-DAT } & \text { board-PASS-PAST }
\end{array}
$$

(Turkish)

'The bus was boarded'.

(/otobüse-e/ 'bus' is not subject because it is in the Dative case)

er wordt door de there become by the jongens gefloten boys whistle-PAST PART. (Dutch)

'There is whistling by the boys.'

(9) bur-ej povali-lo storm-INST knock over-PAST derev-o tree-ACC.

(Russian)

'The tree was knocked over by the storm.'

$$
\begin{aligned}
& \begin{array}{l}
\text { on vendit la maison } \\
\text { one sold the rouse } \\
\text { (French) }
\end{array} \\
& \text { 'The house was sold.' } \\
& \text { (From Siewierska 1984:94-95, } \\
& \text { and Berman 1979: 3) }
\end{aligned}
$$

\subsection{Plain vs. reflexive passives}

Reflexive passives are marked by a reflexive pronoun, which functions as a prefix or a suffix to the main verb. They are commonly found in European languages, as (11)-(13). Passives that are not marked by a reflexive pronoun are plain passives.

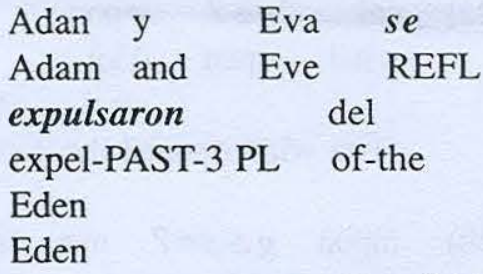

(Spanish)

'Adam and Eve were thrown out of Eden.'

(12)

Nel medio evo si

in-the middle age REFL

bruciavano

burn-IMPERF-3 PL

le streghe

the witch

(Italian)

'In the middle ages witches were burned.'

O Nickos skoto-

Nick kill-REFL-3 S-PAST

apo tus exerus

by the enemy

(Greek)

'Nick was killed by the enemy.'

(From Siewierska 1984:165-165)

\subsection{Synthetic vs. periphrastic passives}

Passives may be divided into two types: synthetic and periphrastic, according to how they are marked

Synthetic passives are marked by affixation to the verb, which turns an active verb into a passive form. These passives are labeled "strict morphological passives" by Keenan (1990: 251). Examples (14b) and (15b) are synthetic passives. The passive verbs are derived from their active counterparts by affixation (14a, 15a). 

(14a) cal pa? mpon
wind open door

'The wind opened the door.'

mpon gə-pa? mə cal door PASS-open by wind 'The door was opened by the wind.'

ha-saba gidel
the-grandfather brought up
et ha-yeled
DO the-child

(Hebrew)

'The grandfather brought up the child.'

(15b) $\begin{array}{ll}\text { ha-yeled } & \text { gudal } \\ \text { the-child } & \text { was brought up } \\ \text { al yedei } & \text { ha-saba } \\ \text { on hands } & \text { the-grandfather }\end{array}$ (Hebrew) 'The child was brought up by the grandfather.'

On the other hand, periphrastic passives are marked by certain words added in active constructions, turning them into passive ones. Such words are normally verbs that may be grouped into four types: 1) verbs meaning 'be, become', 2 ) verbs meaning 'get, receive', 3 ) verbs meaning 'go, come', 4) verbs meaning 'suffer, touch, undergo'.

\section{Periphrastic passives with a verb meaning 'be, become'}

English passives are periphrastic with the verb 'to be', as in (16), (17). German and Persian make use of the verb meaning 'become', as in (18), and (19), respectively.
(16) The project was finished.

(17) The book was written by a Nobel Prize winner.

Hans wurde von
Hans become by
seinem Vater bestraft
his father punished

(German)

'Hans was punished by his father.'

Ahmed košté šod

Ahmed killed become

(Persian)

'Ahmed was killed.'

(From Keenan 1990: 257)

\section{Periphrastic passives with a verb meaning 'get, receive'}

In Welsh, passives are formed by adding the verb 'get', as in (20).

$$
\begin{array}{lll}
\text { cafodd } & \text { Wyn ei rybuddio } \\
\text { get } & \text { Wyn } & \text { his warning } \\
\text { gan } & \text { Ifor } & \\
\text { by } & \text { Ifor } &
\end{array}
$$

'Wyn was warned by Ifor.'

(Keenan 1990: 259)

In English, the verb 'get' may replace the verb 'be' in a passive sentence; e.g., he got kicked, but its occurrence is limited to certain verbs and certain situations. Similarly, in Thai the verb /dây-ráp/ 'receive' may also mark a passive; e.g., /khăw dây-ráp tén-tây/ 'He was appointed.' However, its occurrence is also limited-the verb /dây-ráp/ occurs only with a verb that has a favorable meaning. (See 4.8.) 


\section{Periphrastic passives with a verb meaning 'go, come'}

According to Siewierska (1984), periphrastic passives with a verb meaning 'go', or 'come' are less common than those with other verbs. The verb 'go' or 'come' has lost its lexical meaning and become a passive marker, as can be seen in (21) and (22), which are periphrastic passives in Hindi marked by the verb 'go'. Note that $(21)$ is a personal passive and that (22) is an impersonal one.

Example (23) is a periphrastic passive marked by the verb 'come' in Italian.

$$
\begin{aligned}
& \text { murgi mari gayee } \\
& \text { chicken killed went } \\
& \text { (Hindi) }
\end{aligned}
$$

'The chicken was killed.'

(Keenan 1990: 260)

larko se soyee nahi gayee boys by slept not went

(Hindi)

'It was not slept by the boys.'

(Siewierska 1984: 105)

\author{
la barca viene \\ the boat come \\ affondata \\ sink-PAST-PART \\ (Italian) \\ 'The boat is (being) sunk.'
}

(Siewierska 1984: 134)

Pranee Kullavanijaya (p.c.) points out that in Thai the verb /maa/ 'to come' is normally found in intransitive sentences with a passive meaning, such as (24) and (25), and asks whether such constructions should be regarded as periphrastic passives marked by 'come'.
(24)

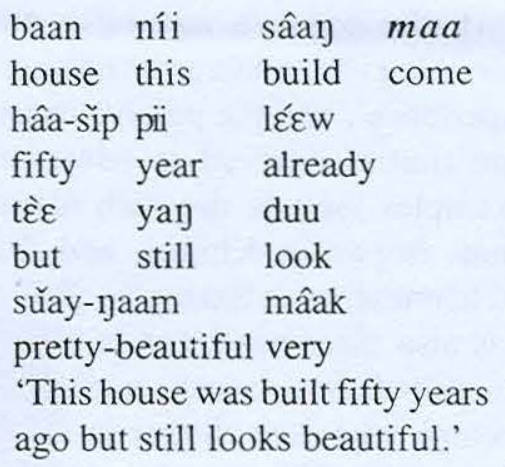

(25)

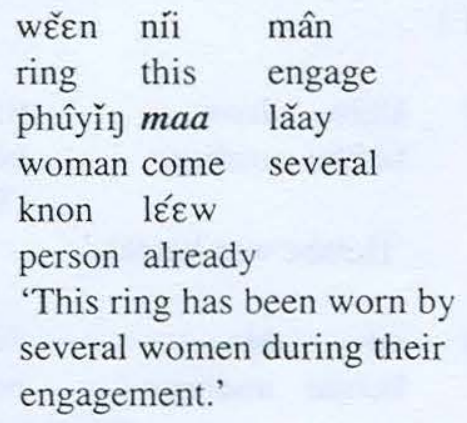

In my opinion, (24) and (25) could be analyzed as unmarked passives if we base the analysis on semantic criteria. The word /maa/ 'come' in these sentences cannot be regarded as a passive marker because it can be omitted. However, it seems to convey the meaning of perfecrive aspect and makes the sentences more intelligible. The claim that the passive is highly compatible with perfective aspect has been suggested in some studies, such as Kulikov (2004), and Toyota \& Mustafovic (2004). However, in order to confirm such a relationship, more specific investigations need to be carried out in more languages, including Thai.

\section{Periphrastic passives with a verb meaning 'suffer, touch, undergo'}

This type of periphrastic passive is commonly found in Southeast Asian languages. The verb that is added to 
mark the passive normally means something like 'undergo an unfavorable experience', and the passive construction that is derived is adversative. Examples include the verb/doon/ in Thai, /trew/ in Khmer, and /bi/ in Vietnamese, as in Examples (26)-(28). It is also discovered that in Malaysia, the verb /kena/ 'touch, undergo' has become a passive marker in the same line, as in (29) (See Prasithrathsint 2001.)

$$
\begin{array}{ll}
\text { khăw doon } & \text { tii } \\
\text { he/she undergo } & \text { beat } \\
& \text { (Thai) }
\end{array}
$$

'He/she was beaten.'

$$
\begin{array}{lll}
\text { nó } & \boldsymbol{b} i & \text { đánh } \\
\text { he/she } & \text { undergo } & \text { beat }
\end{array}
$$$$
\text { (Vietnamese) }
$$

'He/she was beaten.'

$$
\begin{array}{lc}
\begin{array}{l}
\text { ki: traw } \\
\text { he/she undergo }
\end{array} & \begin{array}{r}
\text { wəy } \\
\text { beat } \\
\text { (Khmer) }
\end{array} \\
\begin{array}{ll}
\text { 'He was beaten.' } & \\
\text { budak jahat } & \text { itu } \\
\text { boy naughty } & \text { the } \\
\text { kena pukul } & \\
\text { undergo beat }
\end{array}
\end{array}
$$

'The naughty boy was beaten.'

As can be seen, the features "periphrastic" vs. "synthetic" are based on syntactic criteria. In contrast, the features "neutral" and "adversative" in the Section 4.8 below are based on semantic criteria.

\subsection{Neutral passive vs. adversative or favorable passives}

Passives in most languages of the world are neutral; i.e., they are not limited to either favorable or unfavorable meanings of the verbs or the sentences. European languages have this type of passive. However, in certain languages in Asia, including Thai, passives can have specialized meanings in terms of favorable or unfavorable, especially from the point of view of the speaker. Examples (26)-(29) shown in the previous section are adversative passives in some Southeast Asian languages. Example (30) is a favorable passive in Thai marked by the word /dây-ráp/.

$$
\begin{aligned}
& \text { Somchai dây-ráp lîak } \\
& \text { Somchai receive elect } \\
& \text { pen khaná-bodii } \\
& \text { be dean }
\end{aligned}
$$

'Somchai was elected Dean

The verb /dây-ráp/ 'receive' normally occurs with verbs that have favorable meanings, such as those meaning 'elect, appoint, give (by the king), admire, praise, invite, etc.'

\subsection{Basic vs. non-basic passives}

Basic passives are defined here according to Keenan (1990: 247) as passives which have these three characteristics: 1) There is no agent, 2) the main verb (in its non-passive form) is transitive, and 3) the main verb expresses an activity, taking agent subjects and patient objects. Other passives that do not have these characteristics are non-basic passives. Basic passives are more widespread across the world's languages than nonbasic ones. Examples (31) and (32) are basic passives. 
My book was stolen.

Twenty bodies have been discovered.

\section{Passives with patient subjects vs. passives with non-patient subjects}

Passives may vary according to the role of the subject. Normally, the subject of a passive sentence is the Patient or Objective case relation. However, the subjects of some passive sentences are in other case relations, such as (33)-(35).

\section{This bed (LOCATIVE) has} been slept in.

Mary (DATIVE) was given flowers by John.

\section{The ruined castle walls} (LOCATIVE) were crept over by ivy.

This type of passive is also referred to as "prepositional passive" (e.g., Couper-Kuhlen 1979, Gwang-Yoon 2000). In English, the occurrence of the passive with non-patient subjects is limited. In some other languages, the non-patient subject can be Instrumental, as in (36) and (37). However, it is not marked by a preposition.

$$
\begin{aligned}
& \text { nanasan-dRasoa } \\
& \text { washed with-(INST) by } \\
& \text { Rasoa } \\
& \text { ny lamba ny savony } \\
& \text { the clothes the soap } \\
& \text { (Malagasy) } \\
& \text { 'The soap was washed the } \\
& \text { clothes with by Rasoa.' }
\end{aligned}
$$

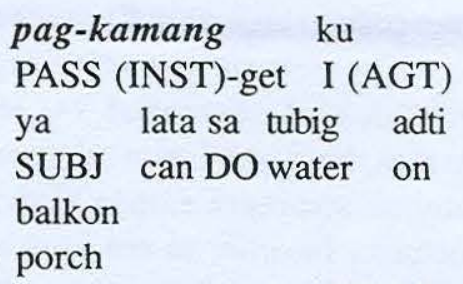

(Kalakan)

'The can will be got water with by me on the porch.'

(Keenan 1990: 279-280)

\section{Types of Passive in Thai}

Based on the categorical criteria used in classifying passives and certain passive-like constructions in the world's languages into 10 pairs shown in Section 4, I classified passive and passive-like constructions in Thai into types. $^{3}$ Table 1 shows that only 6 criteria are applicable to Thai. The rest do not apply because Thai does not have those types of passive.

The six categories that are applicable to Thai are:

1) true passive vs. pseudo-passive

2) direct passive vs. indirect passives

3) sentential passive vs. lexical passives

4) synthetic passive vs. periphrastic passives

5) neutral passive vs. adversative or favorable passives

6) basic passive vs. non-basic passives

\footnotetext{
${ }^{3}$ The data used in the analysis were a large number of concordances taken from an electronic corpus of Thai supplied by the Department of Linguistics, Chulalongkorn University and from current usage of Thai in newspapers and magazines. The total length of the texts from which data were taken was approximately three millions words.
} 
In this paper I take only five categories into consideration, excluding the dichotomy of sentential vs. lexical passives because I aim to focus on sentence structure rather than word structure. In order to see how all the criteria interact and what the system of all the actual passives in Thai is like, I apply a componential analysis to the classification. Note that all the dichotomies are reinterpreted as a system of binary features shown by the + and - signs and rearranged from the broadest features to the narrowest, as follows:

1) [+true], [-true] (true passive vs. pseudo-passive)

2) [+neutral], [-neutral] (neutral vs. adversative or favorable passives)

3) [+direct], [-direct] (direct vs. indirect passives)

4) [+basic], [-basic] (basic vs. nonbasic passives)

5) [+synthetic], [-synthetic] (synthetic vs. periphrastic passives)

Table 1 Criteria applicable to classification of passives in Thai

\begin{tabular}{|c|c|}
\hline \multirow[t]{2}{*}{$\begin{array}{l}\text { Criteria used in classifying passives in the world's } \\
\text { languages }\end{array}$} & \multirow[b]{2}{*}{$\overline{\mathrm{Apl}}$} \\
\hline & \\
\hline \multicolumn{2}{|l|}{ Passive vs. ergative } \\
\hline True passive vs. pseudo-passive & $\bar{x}$ \\
\hline Direct passive vs. indirect passive & $\bar{x}$ \\
\hline Sentential passive vs. lexical passive & $\mathrm{x}$ \\
\hline \multicolumn{2}{|l|}{ Personal passive vs. impersonal passive } \\
\hline \multicolumn{2}{|l|}{ Plain passive vs. reflexive passive } \\
\hline Synthetic passive vs. periphrastic passive & $\bar{x}$ \\
\hline Neutral passive vs. adversative passive & $\bar{x}$ \\
\hline Basic passive vs. non-basic passive & $\bar{x}$ \\
\hline $\begin{array}{l}\text { Passives with patient subjects vs. } \\
\text { passives with non-patient subjects }\end{array}$ & \\
\hline
\end{tabular}

The system of passives in Thai is shown in Figure 1.

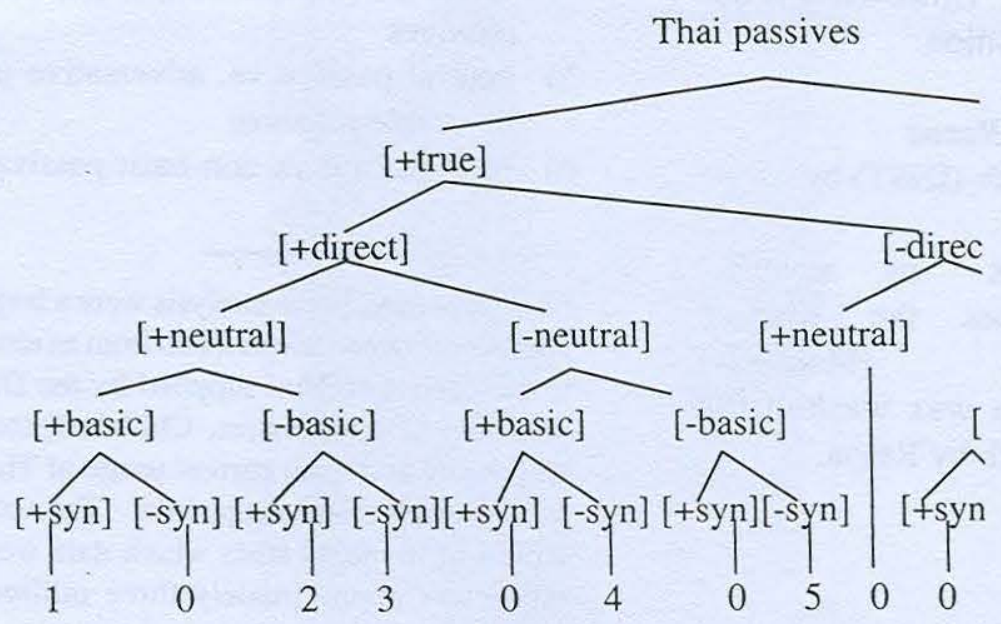

Figure 1 Typological system of passive in Thai 
As can be seen in Figure 1, there are 16 possible types of passive based on the combinations of features under the [+true] category. However, in actuality, there exist only 7 types of true passive (numbered as 1-7 in Figure 1) and one type of pseudo-passive (Number 8) in Thai. The rest marked by 0 do not exist.

\section{Type 1: The [+direct, +neutral, +basic, +synthetic] passive}

This is the most common form of passive in Thai. Even though it is considered a new form, having emerged in the language because of English influence, it is used widely and has become more acceptable among Thai grammarians now than it was a few decades ago. The structure of this type of passive is marked by the lack of an agent phrase and the passive marker /thùuk- $/$, which functions like a prefix to the main verb. Also, the meaning of the passive sentence is neutral, such as (38).

$$
\begin{aligned}
& \text { còtmăay thuìk-sòn } \\
& \text { letter PASS-send } \\
& \text { pay lécw } \\
& \text { go already } \\
& \text { 'The letter was sent/ has been } \\
& \text { sent.' }
\end{aligned}
$$

\section{Type 2: The [+direct, +neutral, -basic, +synthetic] passive}

This type of passive differs from Type 1 in only one feature; i.e., it has an agent phrase, as in (39).

$\begin{array}{ll}\text { aakhaan } & \text { lăy nii } \\ \text { building } & \text { CLS this } \\ \text { thuìk-sâa } & \text { dooy } \\ \text { PASS-build } & \text { by } \\ \text { sathăapaník } & \text { ameerikan } \\ \text { architect } & \text { American }\end{array}$

'This building was built by an American architect.'

\section{Type 3: The [+direct, +neutral, -basic, -synthetic] passive}

This type of direct and neutral passive is different from Type 2 in only one feature: it is not synthetic. The passive marker is not attached to the verb, but is a verb itself and is part of the whole sentence. Note that even though it has the same form as the marker in Type 1 and Type 2-/thùu/, I treat it as a separate item. Also, the agent is not preceded by the preposition 'by' but functions as the subject NP of the embedded clause-/khwaam-rák bòtbay/in (40).

$\begin{array}{ll}\text { khwaam-cin } & \text { thùk } \\ \text { truth } & \text { PASS } \\ \text { khwaam-rák } & \text { bòtban } \\ \text { love } & \text { conceal } \\ \text { 'Truth is concealed by love.' }\end{array}$

Type 4: The [+direct, -neutral, +basic, -synthetic] passive

This type of direct and basic passive is not neutral and not synthetic. It is normally marked by the verb/doon/ 'undergo (an unfavorable experience)', which marks adversity, as in (41) or /dây-ráp/ 'receive (something favorable)', as in (42).

$$
\begin{aligned}
& \text { mǎa doon tii }{ }^{4} \\
& \text { dog PASS beat } \\
& \text { 'The dog was beaten.' }
\end{aligned}
$$

\footnotetext{
${ }^{4}$ In this sentence, /doon/ may be replaced by /thùuk/. Then the meaning would become more neutral. So I do not consider /thùuk/ as a marker in this category.
} 


$$
\begin{aligned}
& \text { khăw dây-ráp tèntân } \\
& \text { he PASS appoint } \\
& \text { pen prathaan boวrisàt } \\
& \text { be chair company } \\
& \text { 'He was appointed chair of the } \\
& \text { company.' }
\end{aligned}
$$

Type 5: The [+direct, -neutral, -basic, -synthetic] passive

This type of passive is similar to Type 4 , but differs from it in only one characteristic: it has an agent, as in (43).

$$
\begin{aligned}
& \text { măa doon phôs tii } \\
& \text { dog PASS father beat } \\
& \text { 'The dog was beaten by Father.' } \\
& \text { (adversative passive) }
\end{aligned}
$$

It must be remarked here that the /dâyráp/ passive, which is always favorable, is not found with an agent, in the same pattern as (43).

\section{Type 6: The [-direct, -neutral, +basic, -synthetic] passive}

This type of basic passive is indirect, non-neutral, and non-synthetic. It is marked by the non-patient subject, as in (44) and (45). Only adversative passives are found to belong to this type. (Also see detail in 4.8).

$$
\begin{aligned}
& \text { phâan thuiuk } \boldsymbol{k}^{5} \text { khamooy yən } \\
& \text { friend PASS steal money } \\
& \text { '(my) friend was affected by his } \\
& \text { money being stolen.' }
\end{aligned}
$$

\footnotetext{
${ }^{5}$ Even though the meaning of the /thùuk/ passive marker tends to be neutral in today usage, in Type 6 and Type 7, which are indirect passives, the original meaning of /thùuk/ ('undergo an unfavorable experience) seems to be preserved. In this case, I consider it here an adversative indirect passive marker.
}

khăw doon khón bâan he PASS search house 'He was affected by his house being searched.'

\section{Type 7: The [-direct, -neutral, - basic, -synthetic] passive}

This type of passive is almost the same as Type 6, but differs from it in that it has an agent, as in (46).

$$
\begin{aligned}
& \text { phîan thùuk coon khamooy } \\
& \text { friend PASS thief steal } \\
& \text { yən } \\
& \text { money } \\
& \text { '(my) friend was affected by his } \\
& \text { money being stolen by a thief.' } \\
& \text { khăw doon tamrùat } \\
& \text { he PASS police } \\
& \text { khón bâan } \\
& \text { search house } \\
& \text { 'He was affected by his house } \\
& \text { being searched by the police.' }
\end{aligned}
$$

\section{Type 8: The pseudo-passive}

The pseudo-passive in Thai is similar to a passive-having the same marker, but its main verb is not derived from a transitive verb, as in (48), marked by /thùuk/ and (49) marked by /doon/. (See also examples in Section 4.9)

$$
\begin{aligned}
& \text { sùda thùuk maa } \\
& \text { Suda PASS come } \\
& \text { sămphâat wan-phrûng-nii } \\
& \text { interview tomorrow } \\
& \text { 'Suda is made to come for an } \\
& \text { interview tomorrow.' }
\end{aligned}
$$




$$
\begin{array}{lll}
\text { chăn doon pay } & \\
\text { I PASS go } & \\
\text { yaan-ť̀nyaan săam hǒn } \\
\text { party-wedding three time } \\
\text { nay dian ní } \\
\text { in month this }
\end{array}
$$

'I have been made to go to three wedding parties this month.'

\section{Conclusion}

In the preceding pages, I have attempted to show a typological classification of Thai passives by applying the universal characteristics of "passives" drawn from previous studies and analyses of passives in the world's languages. The result yields quite a neat system of 7 types of passive and a pseudo-passive in Thai.
Typologically speaking, Thai has 10 categories of passive. They can be grouped into 5 pairs: (1) basic and nonbasic passives; (2) direct and indirect passives; (3) neutral and non-neutral passives; (4) synthetic and periphrastic passives; and (5) true passive and pseudo-passive. From these, only seven true types of passives and one pseudo type that actually exist in Thai are found. They are marked by four markers: 1 ) /thùuk-I, the neutral syn-thetic passive marker; 2)/thùuk, an auxiliary marking a non-basic periphras-tic passive; 3 ) /doon/, an adversative passive marker, and 4) /dây-ráp/, a favorable passive marker. All seven true types of passive and their markers can be seen easily in the following matrix.

Table 2 Matrix of types of passive in Thai and their markers

\begin{tabular}{|c|c|c|c|c|c|}
\hline & Direct & neutral & basic & synthetic & true \\
\hline Type 1 & + & + & + & + & + \\
\hline Type 2 & + & + & - & + & + \\
\hline Type 3 & + & + & - & - & + \\
\hline Type 4 & + & - & + & - & + \\
\hline Type 5 & + & - & - & - & + \\
\hline Type 6 & - & - & + & - & + \\
\hline Type 7 & - & - & - & - & + \\
\hline Type 8 & & & & & - \\
\hline
\end{tabular}




\section{References}

Beedham, Christopher. 2001. Participial passive and aspect in Russian. Word 52 (1), 79-94.

Bennett, P.A. 1980. English passives: A study in syntactic change and relational grammar. Lingua 51.1, 101-114.

Berman, Ruth A. 1979. Form and function: Passives, middles, and impersonals in modern Hebrew. Berkley Linguistic Society 5, 1-27.

Bresnan, J.W. 1978. A realistic transformational grammar. In Linguistic Theory and Psychological Reality, edited by M. Halle, J. Bresan and G. Miller. Cambridge, Mass.: MIT Press.

Chomsky, Noam. 1965. Aspects of Theory of Syntax. Cambridge, Mass.: MIT Press.

Chomsky, Noam. 1973. Conditions on transformations. In A Festschrift for Morris Halle, edited by S. Anderson and P. Kiparsky. New York: Holt, Rinehart and Winston.

Couper-Kuhlen, Elizabeth. 1979. The prepositional passive in English: a semantic-syntactic analysis, with lexicon of prepositional verbs. Tubingen: Niemeyer.

Emonds, Joseph. 1976. A Transformational Approach to English Syntax. New York: Academic Press.

Fillmore, Charles J. 1968. The case for case. Universals in Linguistic Theory, edited by Emmon Bach and Robert T. Harms, 1-88. New York: Holt, Rinehart and Winston.

Fillmore, Charles J. 1971. Some problems in case grammar. Working Papers in Linguistics 10, Ohio State University, 245-265.

Gwang-Yoon, Goh. 2000. The Synchrony and Diachrony of the English Prepositional Passive. Ph.D. dissertation, Ohio State University.
Givón, Talmy. 1979. On Understanding Grammar. New York: Academic Press.Gwang-Yoon, Goh. 2001. The advent of the prepositional passive: An innovation of Middle English? English Studies, 82 (3), 203-217.

Irube, Kaneharu. 1984. Argument structure and the out-prefixation. English Linguistics 1, 105-122.

Keenan, Edward. 1990. Passive in the world's languages. Chapter 5 in Language Typology and Syntactic Description-Clause Structure, edited by Timothy Shopen. Cambridge: Cambridge University Press.

Kulikov, Leonid. Passive, Middle, and perfect in Indo-European: Evidence from Vedic. Paper presented at the Workshop on Passive within the $20^{t h}$ Scandinavian Conference of Linguistics, January 7-9m 2004, University of Helsinki, Finland.

Lightfoot, David W. 1979. Principles of Diachronic Syntax. London: Cambridge University Press.

Prasithrathsint, Amara. 1985. Change in the passive constructions in written Thai during the Bangkok period. Ph.D. dissertation, University of Hawaii.

Prasithrathsint, Amara. 1988. Change in the Passive Constructions in Standard Thai from 1802 to 1982. Language Sciences 10 (2).

Prasithrathsint, Amara. 2001. The adversative passive marker as a prominent areal feature of Southeast Asian languages. Paper presented at the SEALS XI, 16-18 May, 2001, Bangkok. To be published in the Proceedings entitled Papers from the $11^{\text {th }}$ Annual Meeting of the Southeast Asian Linguistic Society.

Prasithrathsint, Amara. 2004. Development of the /thuuk/ passive marker in Thai. Paper presented at the Workshop on Passive within the $20^{\text {th }}$ Scandinavian Conference of Linguistics, January 7 $9 \mathrm{~m} \mathrm{2004,} \mathrm{University} \mathrm{of} \mathrm{Helsinki,}$ Finland.

Siewierska, Anna. 1984. The Passive: A Comparative Linguistic Analysis. Australia: Croom Helm Ltd. 
Shopen, Timothy. 1972. A Generative theory of Ellipsis. Ph.D dissertation, University of California, Ann Arbor, Michigan: University Microfilms.

Starosta, Stanley. 1988. The Case for Lexicase. London: Pinter Publishers Ltd.

Toyota, Junichi and Melisa Mustafovic. Passive and Aspect: Evidence from Slavic. Paper presented at the Workshop on Passive within the $20^{\text {th }}$

Scandinavian Conference of Linguistics, January 7-9m 2004, University of Helsinki, Finland.

Wasow, T. 1977. Transformations and the lexicon. In Formal Syntax, edited by P.Culicover, T. Wasow and A. Akmajian. New York: Academic Press, 327-360.

Yumoto, Yoko. 1991. The role of aspectual features in morphology. English Linguistics 8, 104-133. 